\title{
UPAYA MENINGKATKAN KEDISIPLINAN ANAK USIA DINI MELALUI METODE PEMBIASAAN DI TK BINA ANAPRASA KENCANA TAHUN AJARAN 2016/2017
}

\author{
Adinda Purnama, Reviva Safitri, Ester Emerarita Tarigan \\ Surel: adindapurnama44@yahoo.com,revivasafitri26@gmail.com, \\ Estertarigan66@gmail.com
}

\begin{abstract}
Abstrak
Tujuan dari penelitian ini adalah: 1). Untuk mengetahui kedisiplinan anak usia dini di TK Bina Anaprasa Kencana Bandar Khalifah Kecamatan Percut Sei Tuan Kabupaten Deli Serdang. 2). Untuk mengetahui pelaksanaan metode pembiasaan dalam meningkatkan kedisiplinan anak usia dini di TK Bina Anaprasa Kencana Bandar Khalifah Kecamatan Percut Sei Tuan Kabupaten Deli Serdang. 3). Untuk mengetahui kedisiplinan anak usia dini di TK Bina Anaprasa Kencana Bandar Khalifah Kecamatan Percut Sei Tuan Kabupaten Deli Serdang sesudah menggunakan metode pembiasaan. Penelitian ini menggunakan metode Penelitian Tindakan Kelas ( PTK). subjek penelitian yang berjumlah 10 orang anak. Peningkatan kemampuan peserta didik di TK Bina Anaprasa Kencana dapat meningkatkan kedisiplinan melalui metode pembiasaan dilihat berdasarkan observasi awal yang dilakukan dengan rata-rata 10 kategori anak mulai berkembang, pada siklus I pertemuan I dan II dengan nilai rata-rata 12,8 kategori berkembang sesuai harapan dan pada siklus II pertemuan I dan II dengan nilai rata-rata 22 kategori berkembang sangat baik.
\end{abstract}

Kata Kunci: Kedisiplinan, Anak Usia Dini, Metode Pembiasaan

\section{PENDAHULUAN}

Undang-Undang No. 20 Tahun 2003 Tentang Sistem Pendidikan Nasional telah mengamanatkan dilaksanakan pendidikan kepada seluruh rakyat Indonesia sejak usia dini, yakni sejak anak dilahirkan. Disebut secara tegas di dalam undang-undang bahwa Pendidikan Anak Usia Dini (PAUD) adalah:

Pendidikan anak usia dini adalah suatu upaya pembinaan yang ditujukan kepada anak sejak lahir sampai dengan usia 6 tahun yang dilakukan melalui pemberian rangsangan pendidikan untuk membantu pertumbuhan dan perkembangan jasmani dan rohani agar anak memiliki kesiapan dalam memasuki pendidikan lebuh lanjut.Pendidikan adalah usaha secara sengaja dari orang dewasa untuk orang yang belum dewasa dengan pengaruhnya meningkatkan si anak ke dewasaan (matury) agar mampu memikul tanggung jawab moril dari segala segi perbuatan.(Daulay, 2007: 27). Penanaman karakter adalah usaha pembentukan sikap, sifat, ciri-ciri sebuah akhlaq tertentu melalui pembiasaan yang ditanamkan, dimunculkan, dilakukan, dan diperlihatkan. Sudah pasti apa

Tk Bina Anaprasa Kencana Tahun

Tk Bina Anaprasa Kencana Tahun

Tk Bina Anaprasa Kencana Tahun 
yang anak-anak lihat (teladan/sikap, hal-hal yang visual) dan yang mereka terima (pengetahuan/informasi, penjelasan/berbahas, sikap, sense/rasa) akan membentuk pemikiran (konsep/cara berpikir) yang akan membentuk ciri-ciri/karakter diri, untuk dijadikan contoh dan acuan bersikap/berperilaku mereka. Dari bersikap/berperilaku inilah, mewujudkan akhlaq yang menjadi bagian dari dirinya. (Abdusslam, 2012: 79).

Salah satu hal yang peniliti lihat di lapangan masih banyak anak yang belum disiplin seperti belum terbiasa memberikan salam, membaca doa sebelum dan sesudah kegiatan, tepat waktu saat datang ke sekolah, menyusun mainan setelah bermain, mengerjakan tugas sesuai dengan waktu yang diberikan oleh guru. Dalam hal ini guru berperan penting untuk meningkatkan kemampuan perilaku disiplin yang baik pada anak. Daya ingat anak sangat tinggi dan ahli meniru, mereka dengan mudah mengingat hal-hal yang ada dilikungan kehidupan sekitar.

Berdasarkan latar belakang masalah diatas, maka dapat diidentifikasikan beberapa masalah yaitu sebagai berikut: 1). Kurangnya kesadaran diri anak untuk datang tepat waktu ke sekolah. 2). Kurangnya kesadaran diri anak untuk menyalam orang tua dan guru sebelum masuk kelas. 3). Kurangnya kesadaran diri anak untuk berdoa sebelum dan sesudah kegiatan. 4). Kurangnya kesadaran diri anak untuk mengerjakan tugas sesuai dengan waktu yang diberikan guru. 5). Kurangnya kesadaran diri anak untuk menyusun mainan setelah bermain. Rendahnya minat guru untuk membiasakan anak melakukan kedisiplinan

Berdasarkan identifikasi masalah di atas, maka penelitian ini dapat dibatasi pada Upaya Meningkatkan Kedisiplinan Anak Usia Dini Melalui Metode Pembiasaan di TK Bina Anaprasa Kencana Bandar Khalifah Kecamatan Percut Sei Tuan Kabupaten Deli Serdang. Berdasarkan batasan masalah di atas, maka rumusan masalah diperoleh dalam penelitian ini adalah sebagai berikut: 1). Bagaimana kedisiplinan anak usia dini sebelum menggunakan metode pembiasaan di TK Bina Anaprasa Kencana Bandar Khalifah Kecamatan Percut Sei Tuan Kabupaten Deli Serdang?. 2). Bagaimana pelaksanaan metode pembiasaan dalam meningkatkakn kedisiplinan anak usia dini di TK Bina Anaprasa Kencana Bandar Khalifah Kecamatan Percut Sei Tuan Kabupaten Deli Serdang?. 3). Apakah metode pembiasaan dapat meningkatkan kedisiplinan anak usia dini di TK Bina Anaprasa Kencana Bandar Khalifah Kecamatan Percut Sei Tuan Kabupaten Deli Serdang? Berdasarkan rumusan masalah yang telah dikemukakan di atas, maka tujuan dari penelitian ini adalah: 1). Untuk mengetahui kedisiplinan anak usia dini di TK Bina Anaprasa Kencana Bandar Khalifah Kecamatan Percut Sei Tuan Kabupaten Deli Serdang. 2). Untuk mengetahui pelaksanaan metode pembiasaan dalam meningkatkan kedisiplinan anak usia dini di TK Bina Anaprasa Kencana Bandar Khalifah Kecamatan Percut Sei Tuan Kabupaten Deli Serdang. 3). Untuk mengetahui kedisiplinan anak usia dini di TK Bina Anaprasa Kencana Bandar 
Khalifah Kecamatan Percut Sei Tuan Kabupaten Deli Serdang sesudah menggunakan metode pembiasaan.

Adapun manfaat yang diharapkan dari penelitian ini adalah: 1). Manfaat bagi Peneliti; peneliti mampu melakukan perbaikan pada sistem pembelajaran di TK/RA, dapat menyesuaikan metode yang tepat untuk anak TK/RA. 2). Manfaat bagi Anak didik; dapat menanamkan kedisiplinan sejak dini pada diri anak usia dini agar menjadi pribadi yang lebih baik sedini mungkin, dapat membiasakan dirinya dalam melakukan hal-hal yang baik sehingga anak didik sudah terbiasa dan tidak ragu lagi dalam melakukan hal-hal yang baik tersebut. 3). Manfaat bagi Sekolah; memberikan hal yang positif bagi peningkatan metode pembelajaran, sebagai bahan pertimbangan/referensi untuk penelitian tindakan selanjutnya.

\section{Penngertian Disiplin}

Kedisiplinan berasal dari kata disiplin. Isitilah disiplin berasal dari bahasa latin "disciplina" yang menunjuk pada kegiatan belajar dan mengajar. Sedangkan istilah bahasa ingrisnya "discipline" yang berarti: 1) tertib, taat atau mengendalikan tingkah laku, penguasaan diri. 2) latihan membentuk, meluruskan atau menyempurnakan sesuatu, sebagai kemampuan mental atau karakter moral,

hukuman yang diberikan untuk melatih atau memperbaiki. 4) kumpulan atau sistem-sistem peraturan-peraturan bagi tingkah laku.(Amri, 2016: 161) Eugenia Rakhma (2017:60), mengatakan kata disiplin sebagai hukuman dan kekerasan, namun sebaliknya mengajarkan dan mengarahkan. Sebab disiplin itu sendiri berasal dari bahasa latin, disciple yang artinya mengajarkan.

Stara Waji dalam Sofan Amri (2016: 161). Menyatakan bahwa disiplin berasal dari bahasa latin discere yang berarti belajar. Dari kata ini, timbul kata disciplina yang berarti pengajaran atau pelatihan. Dan sekarang, kata disiplin mengalami perkembangan makna dalam beberapa pengertia. Pertama, disiplin diartikan sebagai kepatuhan terhadap peraturan atau tunduk pada pengawasan, dan pengendalian. Kedua disiplin sebagai latihan yang bertujuan mengembangkan diri agar dapat berperilaku tertib.

\section{Pengertian Disiplin Belajar}

Menurut Slemanto (2003: 87) terdapat empat macam disiplin belajar yang dilakukan oleh peserta didik dalam kegiatan belajar di sekolah yaitu: Disiplin peserta didik masuk sekolah diantaranya, keaktifan, kepatuham, dan ketaatan dalam masuk sekolah. (2) Disiplin dalam mengerjakan tugas. (3) Disiplin dalam mengikuti pelajaran di sekolah, adanyanya kektifan, keteraturan, ketentuan, dan ketertiban dalam mengikuti pelajaran yang terarah pada suatu tujuan belajar. (4) Disiplin dalam menaati tata tertib, yakni kesesuaian tindakan peserta didik dengan tata tertib sekolah dengan penuh kesadaran.

Dengan demikian, disiplin sangat penting dalam kehidupan sehari-hari. Jika disiplin sudah tertanam dengan baik maka akan tercipta sebuah peradaban yang bermartabat. Terkait dengan kedisiplinan dalam belajar bahwa seorang anak didik harus memiliki sikap disiplin dalam belajar. Mengerjakan tugas yang 
diberikan oleh guru, menaati semua peraturan sekolah, masuk sekolah tidak boleh terlambat.

\section{Tujuan Disiplin}

Menurut Sylvia Rimm (2003: 47) menjelaskan bahwa disiplin bertujuan mengarahkan anak agar mereka belajar mengenai hal-hal baik yang merupakan persiapan bagi masa dewasa, saat mereka sangat bergantung kepada disiplin diri. Diharapkan kelak disiplin diri mereka akan membuat hidup mereka bahagia, berhasil, dan penuh kasih sayang.

Disiplin moral telah memiliki tujuan jangka panjang dalam menolong anak-anak muda untuk berperilaku dengan penuh rasa tanggung jawab di segala situasi, tidak hanya ketika mereka di bawah pengendalian (pengawasan) orangorang dewasa yang berkepentingan. Disiplin moral menjadi alasan penembangan siswa untuk menghormati peraturan, menghargai sesama, dan otoritas pengesahan (pengakuan guru, rasa tanggung jawab para siswa demi kebaikan sifat (kebiasaan) mereka, dan tanggung jawab mereka terhadap moral di dalam sebuah komunitas di dalam kelas.(Lickona, 2012: 167).

\section{Strategi Penerapan Disiplin}

Bedasarkan hasil penelitian Reisman and Payne dalam Mulyasa dalam H. E Mulyasa dapat dikemukakan 9 cara untuk membina displin anak usia dini, sebagai berikut :

Konsep diri (self concept), strategi ini menekankan bahwa konsep diri masing-masing individu merupakan faktor penting dari setiap perilaku. Untuk menumbuhkan konsep diri, guru disarankan bersikap empatik, menerima, hangat, dan tebuka sehinga peseta didik dapat mengexplorasikan pikiran dan perasaannya dalam menyelesaikan suatu masalah

Keterampilan berkomunikasi (communication skills), guru harus memiliki keterampilan komunikasi yang efektif agar mampu menerima semua perasaan, dan mendorong timbulnya kepatuhan peserta didik.

Konsekuensi-konsekuensi logis dan alami (natural and logical consequences), perilaku-perilaku yang salah terjadi karena peserta didik telah mengembangkan kepercayaan yang salah, terhadap dirinya. Hal ini mendorong munculnya perilaku-perilaku salah. Untuk itu, guru disarankan: a). menunjukkan secara tepat tujuan perilaku yang salah, sehingga membantu peserta didik dalam mengatasi perilakunya, dan, b). memanfaatkan akibat-akibat logis dan alami dari perilaku yang salah.

Klasifikasi nilai (values clarification), strategi ini dilakukan untuk membantu peserta didik dalam menjawab pertanyaan sendiri tentang nilainilai dan membentuk sistem nilainya sendiri.

Analisis Transaksional (trancsional analysis), disarankan guru belajar sebagai orang dewasa, terutama apabila berhadapan dengan peserta didik yang menghadapi masalah. 
Terapi realitas (reality therapy), sekolah harus berupaya mengurangi kegagalan dan meningkatkan keterlibatan. Dalam hal ini guru harus bersikap positif dan bertanggung jawab.

Disiplin yang terintegrasi (assertive discipline), metode ini menekankan pengendalian penuh oleh guru untuk mengembangkan dan mempertahankan peraturan. Prinsip-prinsi modifikasi perilaku yang sistematik diiplementasikan di kelas, termaksud pemanfaatan papan tulis untuk menuliskan nama-nama peserta didik yang berperilaku menyimpang.

Modifikasi perilaku (behavior modification), perilaku salah disebabkan oleh lingkungan, sebagai tindakan remendiasi. Sehubungan dengan hal tersebut, dalam pembelajaran perlu diciptakan lingkungan yang kondusif.

Tantangan bagi discipline (dare to discipline) guru diharapkan cekatan, sangat teroganisasi, dan dalam pengendalian yang tegas. Pendekatan ini mengasumsikan bahwa peserta didik akan menghadapi berbagai keterbatasan pada hari-hari pertama di sekolah, dan guru perlu membiarkan mereka untuk mengetahui siapa yang berada dalam posisi sebagai pemimpin.

\section{Metode Pembiasaan Pada Anak Usia Dini}

\section{Pengertian Metode Pembiasaan}

Metode merupakan cara yang telah teratur dan telah terpikir baik-baik untuk mencapai suatu maksud. Jalan yang hendak ditempuh oleh seseorang supaya seseorang sampai pada tujuan tertentu, baik dalam lingkungan perusahaan, perniagaan, maupun dalam kupasan ilmu pengetahuan dan lainnya (Arief, 2002: 87).

Jadi teori pembiasaan dalam pendidikan adaah proses pendidikan yang berlangsung dengan jalan membiasakan anak didik untuk bertingkah laku, dengan jalan membiasakan yang baik, sebab tidak semua hal yang dilakukan itu baik. (Mansyur, 2016: 110).

Maka metode pembiasaan sangat penting dilakukan sejak dini sehingga akan berdampak besar terhadap kepribadian anak ketika mereka lebih dewasa. Sebab pembiasaan yang telah dilakukan sejak kecil akan melekat kuat diingatan dan menjadi kebiasaan yang tidak dapat dirubah dengan mudah. Dengan demikian metode pembiasaan sangat baik dalam rangka mendidik kedisiplinan anak.

\section{Bentuk-bentuk Pembiasaan}

Pembiasaan merupakan kegiatan yang dilakukan secara terus menerus dan dalam kehidupan sehari-hari anak sehingga menjadi kebiasaan yang baik. Pembiasaan ini meliputi aspek perkembangan moral dan nilai-nilai agama, pengembangan sosio emosional dan kemandirian. Dari program pengembangan moral dan nilai-nilai agama diharapkan dapat meningkatkan ketaqwaan kepada Tuhan yang maha esa dan membantu terbinanya sikap anak yang baik. Dan dengan pengembangan sosio emosional anak diharapkan dapat memiliki sikap 
membantu orang lain, dapat mengendalikan diri dan beriteraksi dengan lingkungannya.(Is Joni, 2010: 63)

Adapun bentuk-bentuk pembiasaan pada anak dapat dilaksanakan dengan cara berikut:

a. Kegiatan rutin, adalah kegiatan yang dilakukan di sekolah setiap hari, misalnya berbaris, berdo'a, sebelum dan sesudah melakukan kegiatan.

Kegiatan spontan, adalah kegiatan yang dilakukan secara spontan, misalnya meminta tolong dengan baik, menawarkan bantuan dengan baik dan menjenguk teman yang sakit.

Pemberian teladan, adalah kegiatan yang dilakukan dengan memberi teladan/contoh yang baik kepa anak, misalnya memungut sampah di lingkungan sekolah dan spontan dalam bertutur kata.

Kegiatan terprogram, adalah kegiatan yang diprogram dalam kegiatan pembelajaran, misalnya makan bersama dan menjaga kebersihan lingkungan sekolah.(Aqib, 2009: 2).

\section{Langkah-langkah Pembiasaan}

Menurut Sani (2016: 154) kegiatan pembiasaan terperogram dalam pembelajaran dapat dilaksanakan dengan perencanaan khusus dalam kurun waktu tertentu untuk mengembangkan pribadi peserta didik secara individual, kelompok, dan atau klasikal sebagai berikut: (1)Biasakan peserta didik untuk bekerja sendiri, menemukan sendiri, dan mengkonstruksi sendiri pengetahuan, keterampilan dan sikap baru dalam setiap pembelajaran. (2)Biasakan melakukan kegiatan inkuiri dalam setiap pembelajaran. (3)Biasakan peserta didik untuk bertanya dalam setiap pembelajaran. (4)Biasakan belajar secara berkelompok untuk menciptakan "masyarakat belajar". (5)Guru harus membiasakan diri menjadi model dalam setiap pembelajaran (6)Biasa melakukakn refleksi pada setiap akhir pembelajaran. (7)Biasakan melakukan penilaian yang sebenarnya, adil, dan transparan dengan berbagai cara. (8)Biasakan peserta didik untuk selalu bekerja sama dan saling menunjang (9)Biasakan belajar dari berbagai sumber. (10)Biasakan peserta didik untuk sharring dengan temannya. (11)Biasakan peserta didik untuk berpikir kritis. (12)Biasakan untuk bekerja sama dan memberikan laporan kepada orang tua peserta didik terhadap perkembangan perilakunya. (13)Biasakan peserta didik untuk berani menanggung resiko. (14)Biasakan peserta didik untuk menanggung resiko. (15)Biasakan peserta didik tidak mencari kambing hitam. (16)Biasakan peserta didik terbuka terhadap kritikan. (17)Biasakan peserta didik mencari perubahan yang lebih baik (18)Biasakan peserta didik terus menerus melakukan inovasi dan improvisasi demi perbaikan selanjutnya.

\section{Anak usia Dini}

Pengertian Anak Usia Dini 
Anak usia dini merupakan kelompok manusia yang berumur 0-6 tahun. Anak usia dini merupakan kelompok anak yang berada dalam proses pertumbuhan dan perkembangan yang besifat unik dalam arti memiliki pola pertumbuhan dan perkembangan. (Arief, 2012: 116).

Sedangkan menurut Aisyah (2008: 13) karakteristik anak usia dini sebagai berikut: memiliki rasa ingin tahu yang besar, merupakan pribadi yang unik, suka berfantasi dan berimajinasi, masa paling potensial untuk belajar, menunjukkan sifat egosentris, memiliki rentang daya konsentrasi yang pendek, sebagai bagian dari makhluk sosial, bermain merupakan dunia masa anak-anak.

\section{Kerangka Berpikir}

Kedisiplinan yang diterapkan guru di TK Bina Anaprasa Kencana Bandar Khalifah Kecamatan Percut Sei Tuan Kabupaten Deli Serdang masih sangat minim dikarenakan guru enggan menegur secara tegas kepada anak dan orang tua anak. Oleh karena itu anak menjadi terbiasa tidak disiplin dan menganggap remeh atas kesalahannya tersebut.

Kemampuan kedisiplinan anak akan membantu mereka dalam kebiasaan melakukan hal-hal baik serta teratur dalam kehidupannya yang sekarang dan berefek sampai kehidupannya yang akan datang/dewasa. Jika guru mampu memberikan serta menanamkan metode pembiaasan kedisiplinan anak, maka anak akan terbiasa dalam melakukan hal-hal yang baik sejak dini.

\section{Hipotesis Penelitian}

Berdasarkan rumusan masalah dan tujuan penelitian, maka hipotesis dari penelitian ini adalah dengan menerapkan metode pembiasaan dapat meningkatkan kedisiplinan anak usia dini di TK Bina Anaprasa Kencana Bandar Khalifah Kecamatan Percut Sei Tuan Kabupaten Deli Serdang Bandar Setia Kecamatan Percut Sei Tuan Kabupaten Deli Serdang.

\section{METODE PENELITIAN}

Penelitian ini menggunakan metode Penelitian Tindakan Kelas ( PTK) yang terdiri dari 2 siklus. Sesuai dengan judul penelitian yang diterapkan maka yang menjadi lokasi penelitian ini adalah TK Bina Anaprasa Kencana Bandar Khalifah Kecamatan Percut Sei Tuan Kabupaten Deli Serdang Sumatera Utara. Adapun waktu penelitian ini dilakukan pada semester II (Genap) Tahun Pelajaran 2016/2017.

Sesuai dengan jenis penelitian ini, peneliti terlebih dahulu melaksanakan observasi awal melalui wawancara dengan salah satu guru terlebih dahulu dan melihat kemampuan siswa melalui observasi tersebut diketahui bahwa siswa kurang dalam berdisiplin. Hal ini menunjukkan bahwa diperlukan suatu cara untuk mengatasi permasalahan tersebut.

1. Pra Tindakan

Sebelum melakukan perencanaan terlebih dahulu mengetahui permasalahan yang ada, dilakukan observasi awal dimana kegiatan ini bertujuan 
untuk mengetahui peningkatan awal kedisiplinan anak dalam proses belajar sehari-hari. Hasil dari observasi ini digunakan sebagai dasar untuk melanjutkan ke tindakan siklus I dan II. Sesuai dengan jenis penelitian ini, yaitu penelitian tindakan kelas, maka penelitian ini dilaksanakan dalam bentuk beberapa siklus, namun dalam penelitian ini direncanakan 2 siklus. Pada siklus I dan siklus II terdiri dari empat tahapan yaitu perencanaan (planning), tindakan (action), pengamatan (observation), refleksi (reflection).

Siklus I

Perencanaan Tindakan

Tahap perencanaan, peneliti bersama guru kelas membahas teknik pelaksanaan tindakan kelas, antara lain:

a. Menentukan tema yang akan diajarkan sesuai silabus dan kurikulum.

b. Menyusun rencana pelaksanaan pembelajaran harian (RPPH).

c. Mempersiapkan lembar observasi anak tentang peningkatan kedisiplinan anak.

Tahap Pelaksanaan

Setelah perencanaan tersusun, maka dilanjutkan ketahap berikutnya yaitu tahap pelaksanaan tindakan. Dalam tahap pelaksanaan tindakan peneliti yang menjadi guru, dan guru kelas dilibatkan sebagai pengamat yang bertugas memberikan masukan dan kritik yang berguna bagi peneliti. Kegiatan yang dilakukan adalah melaksanakan pembelajaran sesuai dengan Rencana Pelaksanaan Pembelajaran Harian (RPPH) yang telah disusun, kegiatan yang dilakukan dalam tahap pelaksanaan ini adalah:

a. Menyapa dan mengenalkan arti disiplin dan apa saja yang harus dilakukan

dalam membiasakan diri anak didik untuk melakukan hal-hal yang baik.

b. Mulai menampilkan gambar tentang kedisiplinan anak usia dini pada anak.

c. Memberikan penjelasan dan tanya jawab mengenai gambar tersebut.

d. Memberikan reward kepada anak yang aktif dalam menjawab pertanyaan.

e. Membimbing anak selama proses pembelajaran berlangsung.

f. Mengamati anak selama proses pembelajaran.

Pengamatan

Peneliti melakukan pengamatan pada saat kegiatan berlangsung untuk melihat keaktifan anak didik pada saat proses pembelajaran. Pengamatan ini bertujuan untuk mengetahui sejauh mana pelaksanaan tindakan dapat menghasilkan perubahan yang sesuai dengan yang dikehendaki.

\section{Refleksi}

Kegiatan refleksi dilakukan dengan mempertimbangkan pedoman mengajar yang dilakukan serta melihat kesesuaian yang dicapai dengan yang diinginkan dalam pembelajaran yang pada akhirnya ditemukan kelebihan dan kekurangan untuk kemudian diperbaiki. Hasil dari refleksi ini digunakan sebagai dasar untuk melaksanakan tahapan siklus berikutnya.

Siklus II 
Pelaksanaan siklus II sama seperti siklus I. Pada siklus II diadakan perencanaan kembali dengan mengacu pada hasil refleksi siklus I. Siklus II merupakan hasil kesatuan dari kegiatan perencanaan (planning), tindakan (action), pengamatan (observation), refleksi (reflection) seperti yang dilakukan pada siklus I. Metode yang belum tuntas pada siklus I diulang kembali disiklus II sebelum masuk ke materi selanjutnya.

\section{Tekhnik Pengumpulan Data}

Teknik pengumpulan data yang digunakan dalam penelitian ini adalah lembar pengamat atau observasi dan dokumentasi. Analisis data adalah suatu cara menganalisis data yang diperoleh selama peneliti mengadakan penelitian. Penelitian ini termasuk penelitian kuantitatif dan kualitatif. Data yang telah diperoleh secara kuantitatif kemudian dianalisis dengan analisis deskriptif persentase. Data kualitatif menerangkan aktivitas siswa yang dapat diperoleh dari lembar observasi. Adapun untuk menghitung persentasi ketercapaian keberhasilan yang diperoleh setiap anak menggunakan rumus:

\section{Persentase $=$}

Yaitu:

$\mathrm{Pi}=-\mathrm{x} 100 \%$

Keterangan:

Pi : hasil pengamatan

f : jumlah skor yang diperoleh anak

$\mathrm{n} \quad$ : jumlah skor total (jumlah nilai tertinggi $\mathrm{x}$ jumlah indikator).

$\mathrm{Xntuk}_{\Sigma_{\Sigma}}$ - memperoleh nilai rata-rata peneliti menggunakan rumus:

Keterangan :

$\mathrm{X}=$ nilai rata-rata

$\square \mathrm{x} \quad=$ jumlah semua nilai anak

$\square \mathrm{n} \quad=$ jumlah anak

\section{Kriteria Penilaian}

Kriteria penilaian pada penelitian ini ditentukan oleh peneliti berdasarkan indikator yang telah dibuat. Maka dalam bentuk persentasi diperoleh sebagai berikut:

(Belum berkembang): jika 1 aktivitas yang nampak $(0-25 \%=$ kurang)

MB (Mulai berkembang): jika 2 aktivitas yang nampak (26-50\% = cukup) BSH (Berkembang Sesuai Harapan): jika 3 aktivitas yang nampak (51-75\%= baik) 
BSB (Berkembang Sangat Baik): jika 4 aktivitas yang nampak $(76-100 \%=$ sangat baik).

\section{HASIL PENELITIAN DAN PEMBAHASAN}

Deskripsi Hasil Penelitian 1. Hasil Observasi

Awal

Sebelum melaksanakan tindakan pada siklus I, dalam penelitian ini terlebih dahulu melakukan observasi awal sebagai refleksi untuk pelaksanaan siklus I. Observasi awal ini dilakukan untuk melihat kedisiplinan anak kelompok A di TK Bina Anaprasa Kencana Bandar Khalifah Kecamatan Percut Sei Tuan Kabupaten Deli Serdang, sebagai subjek penelitian yang berjumlah 10 orang anak

Diagram Batang Peningkatan Kedisiplinan Anak Pada Pra Siklus

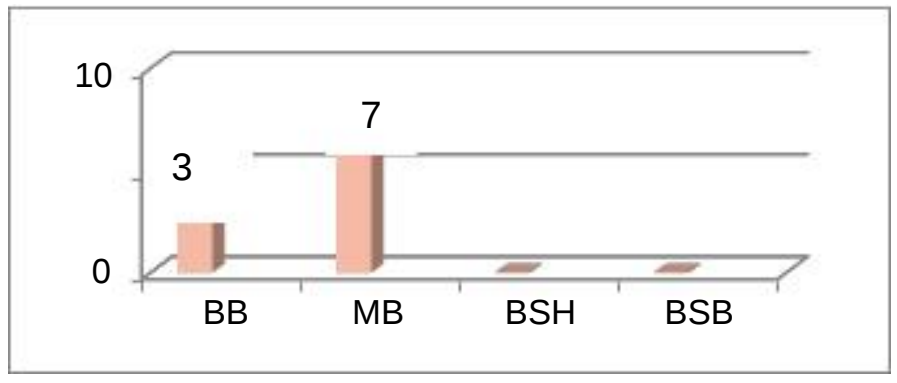

\section{Deskripsi Hasil dan Pelaksanaan Penelitian Siklus I}

\section{Perencanaan Siklus I}

Sebelum melakukan tindakan siklus I, peneliti telah menyusun perencanaan pembelajaran yang dilaksanakan di dalam kelas, antara lain:

Menentukan tema yang akan diajarkan sesuai dengan kurikulum.

Menyusun rencana pelaksanaan pembelajaran dalam bentuk rencana pelaksanaan pembelajaran harian (RPPH).

Mempersiapkan bahan dan peralatan yang akan digunakan

Mempersiapkan lembar observasi siswa tentang kegiatan pembiasaan yang meningkatkan kedisiplinan anak.

\section{Pelaksanaan Siklus I}

Berdasarkan hasil pra siklus pertemuan yang dilakukan peneliti, maka diperoleh hasil bahwa kedisiplinan anak masih rendah, untuk itu penelitian ini dilanjutkan ke siklus I yang dilaksanakan 2 kali pertemuan.

\section{Hasil Siklus I}

Diagram Peningkatan Kedisiplinan Anak pada Siklus IPertemuan I dan Pertemuan II 


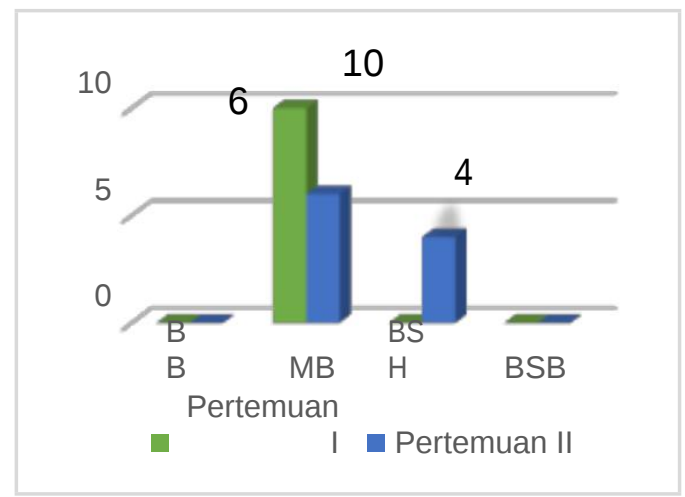

\section{Refleksi Siklus I}

Dari hasil observasi yang telah dilakukan, bahwa kedisiplinan anak sudah ada yang berkembang sesuai harapan oleh karena itu, peneliti akan melakukan perbaikan-perbaikan yang nantinya diharapkan dapat meningkatkan kedisiplinan anak menjadi berkembang sangat baik. Refleksi siklus II yaitu :

Pada tahap ini anak mulai mampu membisakan menyalam orang tua dan guru, berdoa sebelum dan sesudah belajar, menyusun mainan, dan tepat waktu mengumpulkan tugas yang diberikan oleh guru. Akan tetapi hal tersebut masih didasari oleh peringatan dan perintah guru.

\section{Deskripsi Hasil dan Pelaksanaan Penelitian Siklus II}

\section{a. Perencanaan Siklus II}

Sebelum melakukan tindakan siklus I, peneliti telah menyusun perencanaan pembelajaran yang dilaksanakan di dalam kelas, antara lain:

Menentukan tema yang akan diajarkan sesuai dengan kurikulum.

Menyusun rencana pelaksanaan pembelajaran dalam bentuk rencana pelaksanaan pembelajaran harian (RPPH).

Mempersiapkan bahan dan peralatan yang akan digunakan.

Mempersiapkan lembar observasi siswa tentang kegiatan pembiasaan yang meningkatkan kedisiplinan anak.

\section{Pelaksanaan Siklus II}

Berdasarkan hasil siklus I pada pertemuan I dan II dapat dilihat bahwa adanya peningkatan kedisiplinan anak yang dilakukan peneliti, namun peningkatan tersebut belum mencapai kategori berkembang sangat baik dalam arti peneliti masih harus melanjutkan siklus II yang dilakasanakan selama 2 kali pertemuan.

\section{Hasil Observasi Siklus II}

Hasil observasi yang dilakukan oleh peneliti dan guru kelompok A di TK Bina Anaprasa kencana Bandar Khalifah Kecamatan Percut Sei Tuan Kabupaten Deli Serdang menunjukkan bahwa aktivitas peneliti selaku guru selama tindakan 
siklus II dalam kegiatan pembiasaan kedisiplinan lebih meningkat dari hasil pengamatan ketika siklus I

Pertemuan I dan Pertemuan II

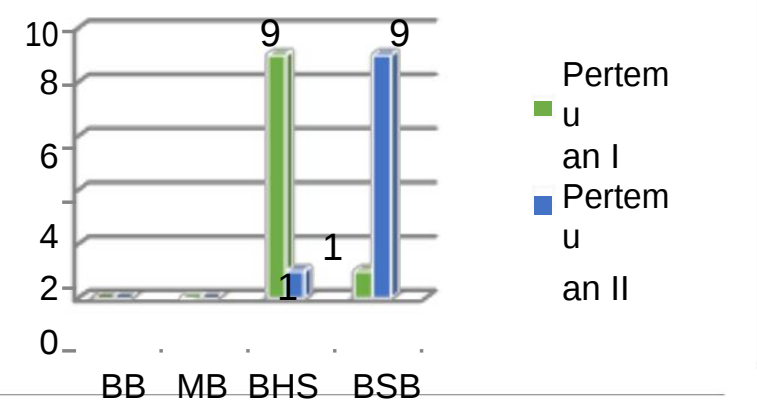

\section{Refleksi Siklus II}

Berdasarkan hasil diskusi, observasi dan dokumentasi yang dilakukan dapat disimpulkan bahwa penelitian tidak dilanjutkan pada siklus berikutnya karena anak sudah mengalami peningkatan kedisiplinan. Hal ini dapat dilihat dari hasil observasi yang semakin membaik dan kedisiplinan anak mengalami peningkatan berdasarkan persentase observasi motorik anak pada siklus II, pertemuan pertama 9 orang yang tergolong kriteria berkembang sesuai harapan, dan 1 orang yang tergolong kriteria berkembang sangat baik, sedangkan pada pertemuan kedua sudah tidak ada lagi pada kriteria kurang maupun cukup, maka hasilnya terdapat 1 orang anak yang tergolong kriteria berkembang sesuai harapan dan 9 orang anak yang tergolong kriteria berkembang sangat baik.

\section{SIMPULAN}

Berdasarkan hasil observasi terhadap penelitian tindakan kelas yang dilakukan selama 2 siklus diperoleh beberapa kesimpulan yaitu:

Kemampuan kedisiplinan anak sebelum menggunakan metode pembiasaan diperoleh 10 anak dengan kategori belum berkembang.

Pelaksanaan kegiatan pembiasaan dalam meningkatkan kedisiplinan anak di TK Bina Anaprasa Keencana pada siklus I kegiatan pembiasaan dilakukan dengan cara guru menjelaskan tujuan dan manfaat kedisiplinan dan pada siklus II pembiasaan dilakukan dengan cara memberi reward kepada anak.

Peningkatan kemampuan peserta didik di TK Bina Anaprasa Kencana dapat meningkatkan kedisiplinan melalui metode pembiasaan. Hal tersebut dapat kita lihat berdasarkan observasi awal yang dilakukan oleh peneliti dengan rata-rata 10 kategori anak mulai berkembang, pada siklus I pertemuan I dan II dengan nilai rata-rata 12,8 kategori berkembang sesuai harapan dan pada siklus II pertemuan I dan II dengan nilai rata-rata 22 kategori berkembang sangat baik.

Berdasarkan kesimpulan di atas, maka peneliti mengajukan beberapa saran yaitu: Bagi guru TK Bina Anaprasa kencana disarankan agar dapat mengajarkan 
pembiasaan-pembiasaan yang membuat anak tertarik dan menyenangkan, sehingga anak terbiasa dan senang melakukan kedisiplinan sedini mungkin pada dirinya, sehingga kedisiplinan anak pun meningkat. Hasil penelitian ini di dukung oleh Masganti Sit, yang mengatakan di dalam ajaran Islam cara mengajar akhlak anak kepada anak usia dini dapat dilakukan dengan berbagai cara antara lain:

Membiasakan anak melakukan hal-hal baik, misalnya membaca doa ketika memulai sebuah pekerjaan dan ketika menyelesaikan pekerjaan.

Memberikan contoh yang baik pada anak setiap perilaku yang ditunjukkan orang tua, guru atau orang dewasa lainnya yang selalu dekat dengan anak.

Memberikan pujian kepada anak yang melakukan perbuatan baik dan memberikan nasehat kepada anak yang melakukan perbuatan buruk Penelitian ini juga didukung oleh Ahmad Tafsir yang menyatakan sebagai berikut:

Pemberian reward pada anak akan menimbulkan perbuatan baik. Oleh karena itu, reward yang diberikan hendaknya memiliki tiga peranan penting untuk mendidik anak dalam berperilaku: a) reward mempunyai nilai mendidik, b) reward berfungsi sebagai motivasi untuk mengulangi berbuat baik, c) reward berfungsi untuk memperkuat perilaku yang lebih baik.

\section{DAFTAR RUJUKAN}

Abdussalam, Surasso. 2012. Cara Mendidik Anak Sejak Lahir Hingga TK. Surabaya: Sukses Publishing.

Aisya, Siti. 2008. Perkembangan dan Konsep Dasra Pengembangan anak Usia Dini,.Jakarta: Universitas Terbuka.

Amri, Sofan. 2016. Pengembangan dan Model Pembelajaran dalam Kurikulum,.Jakarta: Prestasi Pustakarya.

Aqib, Zainal. 2009. Belajar dan Pembelajaran di Taman Kanak-Kanak. Bandung: Yrama Widya.

Arief, Armai. 2002. Pengantar Ilmu dan Metodelogi Pembelajaran Agama Islam. Jakarta: Ciputat.

Daulay, Haidir Putra. 2009. Sejarah Pertumbuhan dan Perkembangan Islam di Indonesia. Jakarta: Kencana, Ed. I.

Isjoni. 2010. Model Pembelajaran Anak Usia Dini. Bandung: Alfabeta.

Lickona, Thomas. Education dor Character mendidik untuk Membentuk Karakter. Jakarta: Bumi Aksara. 
Mansyur, Ahmad. 2016. Pendidikan Karakter Berbasis Wahyu, Jakarta: Gaung Persada.

Rakhma, Eugenia. 2017. Menumbuhkan Kemandirian Anak. Jogjakarta: Diandra Primamitra Media. 